\title{
Turystyka w dokumentach strategicznych gmin wiejskich województwa pomorskiego
}

\section{Tourism in strategic documents of rural communes in the Pomorskie Voivodeship}

\author{
Klaudia Nowicka $\odot$ \\ Uniwersytet Gdański \\ Katedra Geografii Społeczno-Ekonomicznej \\ ul. Bażyńskiego 4a, 80-309 Gdańsk \\ klaudia.nowicka@ug.edu.pl
}

\begin{abstract}
Zarys treści: Za cel niniejszego opracowania autorka postawiła sobie określenie, jakie znaczenie ma turystyka w rozwoju społeczno-gospodarczym gmin wiejskich województwa pomorskiego, na podstawie zapisów dokumentów strategicznych. Aby zrealizować tak postawiony cel autorka poddała analizie dostępne aktualne dokumenty strategiczne dla 74 gmin, korzystając z analizy komputerowej oraz kontekstowej wszystkich dostępnych tekstów. Szczegółowej analizie poddano wybrane fragmenty opracowań, tj. rozdziały dotyczące celów strategicznych i operacyjnych oraz analizy SWOT. Badanie dotyczyło tych celów oraz elementów analizy SWOT, które w sposób bezpośredni związane były z rozwojem turystyki w gminie. Ponadto, analiza pozwoliła na określenie, w jakim stopniu strategie rozwoju gmin wiejskich województwa pomorskiego są narzędziem przydatnym w długofalowym planowaniu rozwoju społeczno-gospodarczego w odniesieniu do rozwoju branży turystycznej w gminie.
\end{abstract}

Słowa kluczowe: turystyka, rozwój lokalny, strategia rozwoju gminy.

\section{Wstęp}

Turystyka jest obecnie najszybciej rozwijającą się, a co za tym idzie, przynoszącą znaczne zyski, gałęzią gospodarki. Branża ta generuje 10\% światowego produktu krajowego brutto (UNWTO Tourism Highlights... 2017). Z tego powodu nazywana jest często kluczem do rozwoju, dostatku i dobrostanu. Niezależnie od tego, jakie zagrożenia ze sobą niesie, społeczne, czy środowiskowe, jest postrzegana jako swego rodzaju gwarant rozwoju społeczno-ekonomicznego regionów (Dogru i Bulut 2018). To przeświadczenie o zbawiennej roli turystyki w rozwoju społeczno-gospodarczym jest powszechne również na poziomie lokalnym i regionalnym, także w Polsce.

Bez wątpienia branża turystyczna działa stymulująco na rozwój gospodarczy regionów (Bosiacki 2016; Szwacka-Mokrzycka 2012; Kozak 2010), jednakże proces rozwoju funkcji turystycznej powinien być odpowiednio planowany, z uwzględnieniem kwestii społecz- 
nych, środowiskowych, przestrzennych i kulturowych. Jednym z podstawowych narzędzi długofalowego planowania rozwoju gmin naszego kraju są strategie rozwoju, czyli dokumenty określające strategiczne cele rozwoju, wytyczające kierunki działań w postaci celów i zadań operacyjnych, wskazujące środki finansowe i źródła niezbędne do realizacji przyjętych celów i zadań (Kłodziński 2009) oraz dostarczające informacji o postrzeganiu samej gminy i jej zasobów poprzez identyfikację szans, zagrożeń, mocnych oraz słabych stron w ramach prowadzonej analizy SWOT. Mimo, iż nie są one dokumentami obligatoryjnymi i żadna ustawa nie zmusza władz lokalnych do ich opracowania, to rzetelnie przygotowane strategie rozwoju, z uwzględnieniem partycypacji lokalnej społeczności, są bardzo przydatnym narzędziem w procesie zarządzania jednostkami terytorialnymi. Ponadto, jak argumentuje M. Kłodziński (2009, s. 33-34), „planowanie [...] musi towarzyszyć każdej władzy i jest niezbędnym elementem dostosowania się do wymogów UE. Dobrze rozwinięte i efektywnie wdrażane planowanie staje się nieodzownym elementem sprzyjającym racjonalności gospodarowania, zwłaszcza środkami publicznymi”. Wśród najbardziej aktualnych krajowych publikacji naukowych znaleźć można liczne opracowania dotyczące roli, jaką spełniają samorządy lokalne oraz dokumenty strategiczne w rozwoju społeczno-gospodarczym jednostek terytorialnych (m.in. Klasik i Kuźnik 2001; Idziak 2002; Bocian 2003; Wojtasiewicz 2003; Lisiński 2004; Wilkisz 2004; Ślusarz 2006; Kłodziński 2009; Sztando 2009, 2011; Gawroński 2010; Brodziński 2011; Kogut-Jaworska 2011; Szewczuk 2011; Wiatrak 2011; Wołowiec i Reśko, 2012; Parysek 2015).

Coraz częściej w dokumentach strategicznych gmin w Polsce uwzględniany jest rozwój branży turystycznej - według badań A. Pawlikowskiej-Piechotki (2013) około 80\% gmin postrzega turystykę, jako podstawowy lub uzupełniający kierunek rozwoju społeczno-gospodarczego. Większość gmin wiejskich województwa pomorskiego posiada aktualną strategię rozwoju, co skłoniło autorkę niniejszego artykułu do postawienia sobie za cel sprawdzenie, w jaki sposób władze lokalne postrzegają turystykę i jakie znaczenie nadają branży turystycznej w procesie długookresowego planowania rozwoju podległych im jednostek terytorialnych.

\section{Obszar badań i metody badawcze}

Województwo pomorskie podzielone jest na 123 gminy, a 81 z nich to gminy wiejskie (ryc. 1), zajmujące zdecydowaną większość obszaru województwa.

Jak już wcześniej wspomniano, większość gmin wiejskich posiada aktualną strategię rozwoju - dokument, który został wybrany jako podstawa prowadzonych przez autorkę analiz. Jedynie 7 jednostek nie przygotowało lub nie zaktualizowało wymienionego wyżej dokumentu. Są to gminy Choczewo, Krokowa, Przywidz, Ostaszewo, Stare Pole, Stary Targ oraz Sadlinki. Według informacji pozyskanych w urzędach gmin strategie te są obecnie na różnych etapach opracowywania. Ostatecznie zatem analiza obejmowała 68 dokumentów strategicznych dla 74 gmin, ponieważ po wnikliwej analizie treści do opracowania zdecydowano się włączyć „Strategię rozwoju społeczno-gospodarczego Kościerskiego Obszaru Funkcjonalnego", która to obejmuje gminy Dziemiany, Karsin, Kościerzyna, Liniewo, Lipusz, Nowa Karczma, Stara Kiszewa - czyli 7 gmin wiejskich powiatu kościerskiego.

Analiza dostępnych aktualnych dokumentów strategicznych obejmowała 4 etapy. $\mathrm{Na}$ każdym z nich zastosowano inne metody i narzędzia badawcze. Na pierwszym etapie 

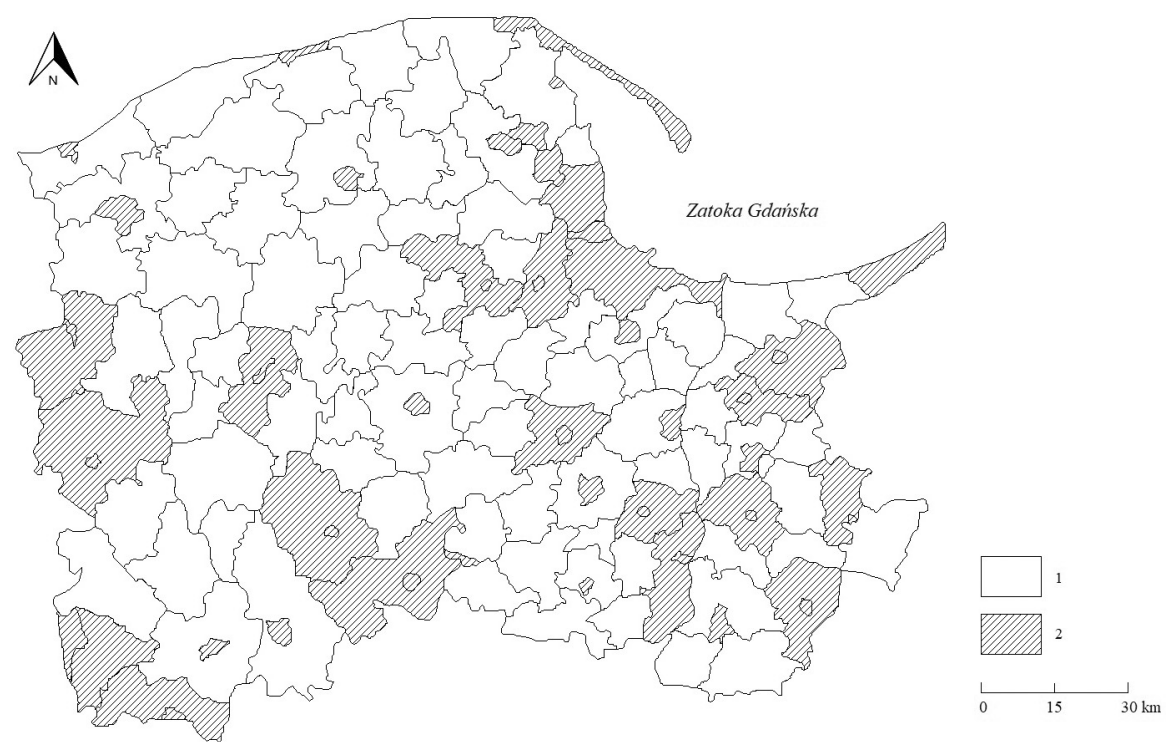

Ryc. 1. Obszar badań na tle podziału administracyjnego województwa pomorskiego Źródło: opracowanie własne, tak samo pozostałe ryciny. 1 - gminy wiejskie, 2 - gminy miejskie i miejsko-wiejskie Research area in relation to the administrative division of the Pomorskie Voivodeship 1 - rural communes, 2 - urban and urban-rural communes Source: own elaboration, as remaining figures.

określono słowa kluczowe, będące podstawą dla analizy komputerowej tekstu - zdecydowano się na wszystkie słowa zawierające rdzeń „turyst”, co pozwalało na automatycznie znalezienie i policzenie wyrazów takich jak: turysta, zagospodarowanie turystyczne, turystyka itp. Wykorzystano w tym celu funkcję zaawansowanego wyszukiwania w programie Adobre Acrobat Pro. Zaś jeśli chodzi o wybór treści analizowanych kontekstowo, bez użycia narzędzi komputerowych, zdecydowano się na fragmenty dokumentów dotyczące celów strategicznych i operacyjnych oraz czterech obszarów analizy SWOT. Są to treści zawarte w każdej strategii, co zapewniło porównywalność wyników badań. Etap drugi obejmował już samą analizę: komputerową całego dostępnego materiału oraz kontekstową wybranych fragmentów. Na etapie trzecim utworzono tablicę zbiorczą dla wszystkich analizowanych jednostek, w której kolejne kategorie obejmowały: typ analizowanego dokumentu, okres planowania, liczbę celów operacyjnych i strategicznych związanych z turystyką wraz z ich treścią, liczbę słów zawierających rdzeń „turyst”, rodzaje turystyki wymienione w dokumencie, a także wszystkie mocne i słabe strony, zagrożenia i szanse, które w jakimś sensie odnoszą się do turystyki. Na etapie 4 wszystkie uzyskane dane zostały zwizualizowane z użyciem metod kartograficznych. 


\section{Turystyka w celach strategicznych i operacyjnych gmin}

Odpowiednio zhierarchizowane, jasno sformułowane i możliwe do realizacji cele strategiczne i operacyjne to podstawa planowania rozwoju społeczno-ekonomicznego gminy i niewątpliwie jeden z najważniejszych elementów dokumentów strategicznych. W ramach prowadzonych analiz kontekstowych określono liczbę celów strategicznych i operacyjnych, które w jakiejś mierze dotyczą rozwoju funkcji turystycznej w gminie. Można przyjąć, że im częściej turystyka pojawia się w tych zapisach, tym istotniejszy jest rozwój branży turystycznej dla władz gminy i mieszkańców (o ile uczestniczyli oni w procesie opracowywania strategii).

Spośród 74 gmin, niemal jedna trzecia (32\%) określiła w dokumentach kwestie związane z rozwojem turystyki jako strategiczne. Cele strategiczne są z zasady formułowane bardzo ogólnikowo, zatem i w przypadku tych związanych z turystyką, ich treść zawiera stwierdzenia ogólne, takie jak „rozwój turystyki” (np. Przodkowo, Sierakowice, Sulęczyno, Stężyca) „rozwój infrastruktury turystycznej” (Bobowo) czy „promocja gminy” (Subkowy). W większości przypadków gminy posiadają tylko jeden cel strategiczny związany z turystyką. Inaczej jest w przypadku celów operacyjnych, które są bardziej szczegółowe i odnoszą się do konkretnych zadań, które mają zostać zrealizowane w wybranej perspektywie czasowej. Jak wskazuje rycina 2, w większości analizowanych gmin rozwój turystyki jest uwzględniony w planowaniu strategicznym. Jedynie 6 spośród jednostek poddanych analizie nie planuje rozwoju funkcji turystycznej i nie wyznaczyło ani jednego celu operacyjnego związanego z turystyką. Z drugiej strony, najwyższy odsetek celów operacyjnych, w których wymieniona została branża turystyczna, wyniósł 38\% dla gminy Przodkowo,

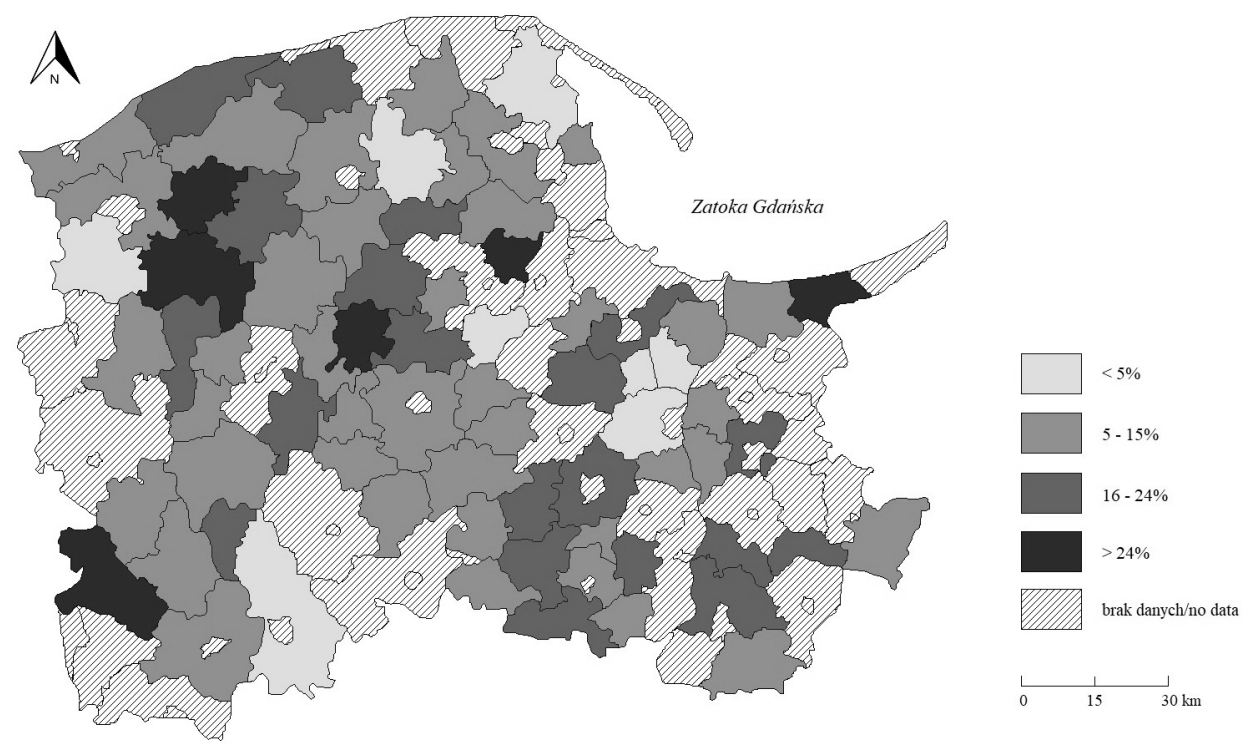

Ryc. 2. Odsetek celów operacyjnych związanych z turystyką w dokumentach strategicznych gmin wiejskich województwa pomorskiego

Percentage of operational objectives related to tourism in strategic documents of rural communes in the Pomorskie Voivodeship 
która nie wyróżnia się ani walorami antropogenicznymi, ani przyrodniczymi, które mogłyby tłumaczyć tak duży nacisk na rozwój branży turystycznej akurat na tym terenie. Innymi gminami, których ponad 1/4 celów strategicznych odnosi się do turystyki, były: Rzeczenica, Damnica, Dębnica Kaszubska, Sulęczyno i Sztutowo. Spośród wymienionych gmin jedynie Sztutowo, położone bezpośrednio nad morzem, swoją lokalizacją uzasadnia przywiązywanie tak dużej wagi do rozwoju branży turystycznej.

W analizowanych dokumentach cele operacyjne związane z turystyką sformułowane są w bardzo różny sposób. Jednakże to, co najbardziej zwraca uwagę, to znaczny poziom ich ogólności. Przykładem mogą być zapisy „Turystyka i rekreacja” (gmina Kaliska) czy też „Rozwój turystyki na terenie gminy” (gminy Kolbudy i Nowa Wieś Lęborska). Jednym z nielicznych przykładów poprawnie sformułowanych, konkretnych i, co istotne, odnoszących się do istniejących zasobów gminy, jest cel operacyjny przyjęty przez gminę Ryjewo w brzmieniu: „Zbudowanie marki produktu regionalnego - przetwory z czarnego bzu". Ponadto, w większości analizowanych dokumentów pojawiają się dokładnie takie same sformułowania. Aż 10 spośród 74 badanych gmin za cel operacyjny stawia sobie „Wspieranie rozwoju turystyki i rekreacji jako czynnika dynamizującego lokalny rozwój gospodarczy" - dokładnie w tym samym brzmieniu. Jeśli chodzi o rodzaj zadań, będących celami operacyjnymi, które gminy wyznaczają sobie do realizacji w przyjętej perspektywie czasowej, to dotyczą one niemal wszystkich aspektów rozwoju funkcji turystycznej, czyli tworzenia oferty, produktu turystycznego, podnoszenia atrakcyjności, promocji walorów gminy, ale przede wszystkim rozbudowy infrastruktury technicznej, np. „Tworzenie warunków w zakresie infrastruktury dla rozwoju masowej turystyki pobytowej” (gmina Lipnica). Analizując cele operacyjne, stawiane sobie przez badane gminy wiejskie województwa pomorskiego stwierdzić można, że rozbudowa infrastruktury oraz dostosowanie/wykorzystanie walorów środowiska naturalnego postrzegane są jako podstawa rozwoju turystyki. Niepokojący wydaje się fakt, że walory przyrodnicze traktowane są dość instrumentalnie - jedynie w dwóch gminach cel operacyjny związany z przekształcaniem środowiska naturalnego dla potrzeb rozwoju branży turystycznej zawierał przymiotnik „zrównoważony” lub inne sformułowanie wskazujące na troskę o środowisko. Takie podejście potwierdza też ewaluacja elementów analizy SWOT, której wyniki przedstawione zostaną w dalszej części opracowania.

\section{Formy turystyki wymieniane w strategiach rozwoju badanych gmin}

Analiza form turystyki wymienianych w analizowanych dokumentach strategicznych objęła w pierwszej kolejności ich kategoryzację. Wszystkie wymienione formy podzielono na 5 kategorii głównych: poznawczą, wypoczynkową, aktywną (kwalifikowaną), zdrowotną, biznesową, religijną. Analiza treści dokumentów strategicznych wykazała, że choć nadal niemal wszystkie gminy wspominają o turystyce wypoczynkowej (głównie w formie agroturystyki), pozostając wiernymi starym paradygmatom, to zauważalne są także istotne zmiany w planowaniu strategicznym w tym obszarze.

Coraz więcej gmin stawia na rozwój turystyki aktywnej, z ogromnym naciskiem na turystykę rowerową, niejednokrotnie cytując postanowienia zapisane w strategii rozwoju województwa. Aż 52 gminy wymieniają ten rodzaj turystyki w swoich dokumentach strategicznych (ryc. 3). 


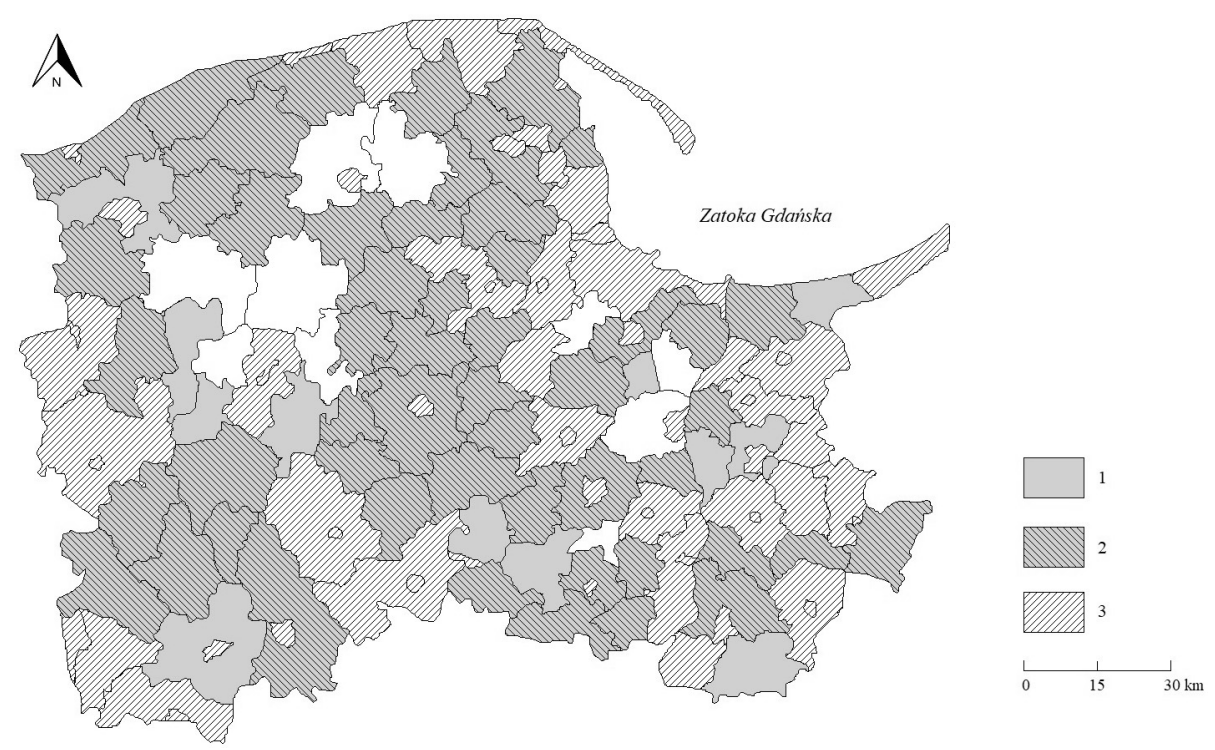

Ryc. 3. Turystyka aktywna oraz rowerowa w dokumentach strategicznych gmin wiejskich województwa pomorskiego

1 - gminy, których strategie wymieniają turystykę aktywną, 2 - gminy, których strategie wymieniają turystykę rowerową, 3 - gminy nieobjęte badaniem

Active tourism and bicycle touring in strategic documents of rural communes in the Pomorskie Voivodeship 1 - active tourism mentioned in strategic documents, 2 - bicycle touring mentioned in strategic documents,

3 -administrative units not included in the analysis

Poza klasycznymi formami turystyki aktywnej, jak piesza (wymieniona w 38 dokumentach), kajakowa, czy żeglarska (różne formy turystyki wodnej wymieniane są przez 35 gmin), niektóre gminy stawiają też na nowe trendy, czyli nordic walking czy geocatching. Ponadto, w dokumentach sześciu gmin wymieniana jest też turystyka narciarska, rozwijana głównie na wzniesieniach morenowe na Kaszubach.

Biorąc pod uwagę dość krótki sezon turystyczny naszego kraju, równie pozytywne jest zwrócenie się ku turystyce opartej na walorach antropogenicznych, kulturowych, które mogą być penetrowane przez turystów również poza sezonem. Lokalne dziedzictwo kulturowe, folklor, rzemiosło, tradycja to walory wymieniane przez 23 gminy również w celach operacyjnych (ryc. 4). Niestety rzadko w odniesieniu do konkretnych obiektów lub obszarów. Wśród wyjątków, odnoszących się do charakterystyki konkretnej gminy, znalazły się następujące sformułowania: „Podjąć działania w kierunku rozwoju turystyki w oparciu o tradycję kaszubską” (gmina Lipnica); „Turystyczne wykorzystanie walorów dziedzictwa kulturowego i naturalnego związanego z położeniem na Żuławach Wiślanych" (gmina Miłoradz); „Wykorzystanie Pałacu w Stążkach do wszechstronnego rozwoju i promocji gminy" (gmina Mikołajki Pomorskie).

Pozostałe kategorie, obejmujące turystykę zdrowotną, biznesową i religijną, są wymieniane sporadycznie. Turystyka zdrowotna została wymieniona w dokumentach dwóch gmin: Pszczółki i Puck. W przypadku gminy Pszczółki rozwój turystyki zdrowotnej powiązany jest z ofertą zdrowej żywności, w tym Miodu Pszczółkowskiego, będącego produktem 


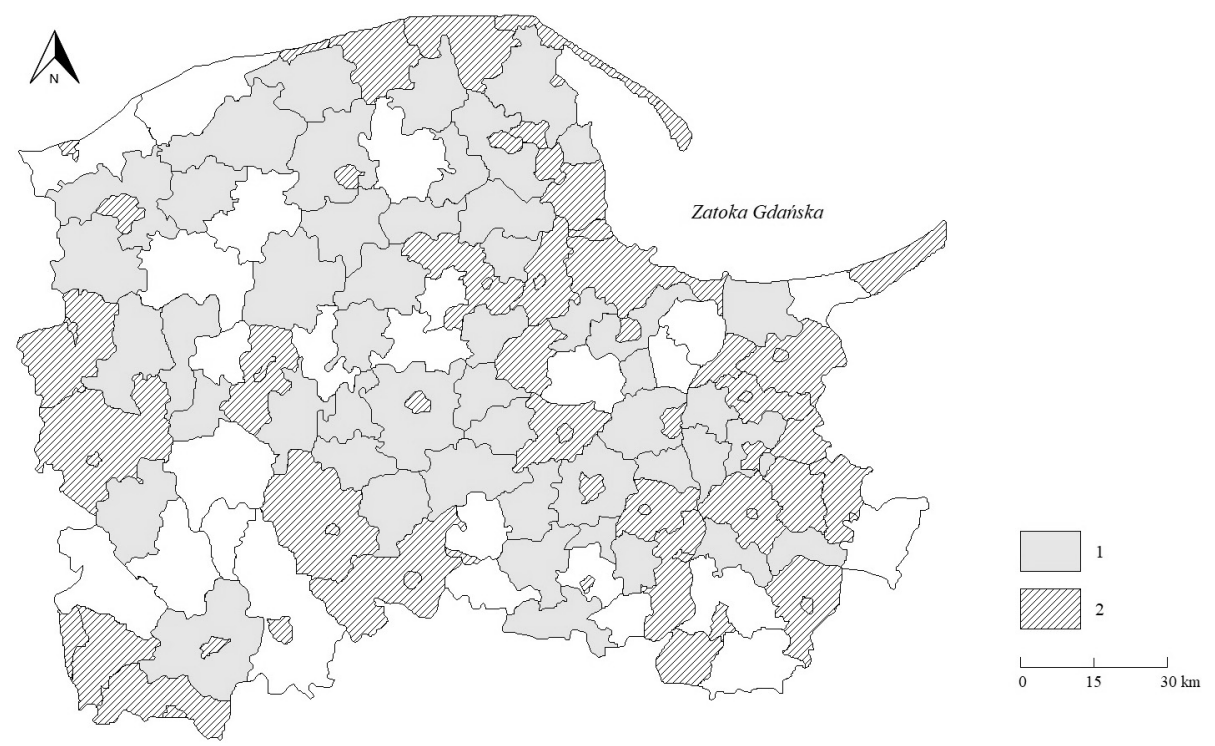

Ryc. 4. Turystyka poznawcza w dokumentach strategicznych gmin wiejskich województwa pomorskiego 1 - gminy, których strategie wymieniają turystykę poznawczą, 2 - gminy nieobjęte badaniem Cognitive tourism in strategic documents of rural communes in the Pomorskie Voivodeship 1 - cognitive tourism mentioned in strategic documents, 2 -administrative units not included in the analysis

tradycyjnym. Natomiast w gminie Puck turystyka zdrowotna wynikająca z mody na zdrowy styl życia oraz powiązana z procesem starzejącego się społeczeństwa postrzegana jest jako szansa rozwojowa, wymieniona w analizie SWOT. Turystyka biznesowa wymieniona została w dokumentach dwóch gmin wiejskich: Gniewino oraz Czarna Dąbrówka. W gminie Gniewino zapis ten odnosił się do już realizowanych wydarzeń, takich jak: szkolenia, konferencje i sympozja, organizowanych m.in. w Hotelu Mistral Sport oraz w dworach i pozostałych obiektach dysponujących odpowiednim zapleczem, natomiast w gminie Czarna Dąbrówka rozwój turystyki biznesowej wymieniony został jako jeden z sektorów rozwoju lokalnych firm, razem z innowacyjnymi formami ekoturystyki. Rozwijanie turystyki religijnej zwykle łączy się z obecnością na danym terenie obiektów sakralnych o wyjątkowej wartości. W przypadku gmin wiejskich województwa pomorskiego, tego typu forma turystyki wspomniana jest w strategiach rozwoju dwóch gmin - Pszczółki oraz Miłoradz. W gminie Pszczółki turystów religijno-pielgrzymkowych przyciągają z sakralne obiekty pocysterskie, a w gminie Miłoradz Sanktuarium błogosławionej Doroty w Mątowach Wielkich.

Zmiany w postrzeganiu turystyki, jako sektora rozwijanego w gminach, dotyczą również czasu trwania pobytu turystów w gminie. Zwłaszcza gminy wiejskie nieposiadające w swych zasobach znacznych walorów turystycznych winny stawiać na krótsze pobyty oraz weekendowe przyjazdy mieszkańców Trójmiasta i innych dużych miast regionu.

Turystyka weekendowa lub krótkoterminowa została wspomniana w strategiach rozwoju 33 gmin (45\% wszystkich badanych) (ryc. 5). Zwrot ku krótszym pobytom łączy się z promowaniem aktywnych form spędzania czasu wolnego i tworzeniem infrastruktury umożliwiającej uprawianie różnych form turystyki kwalifikowanej. 


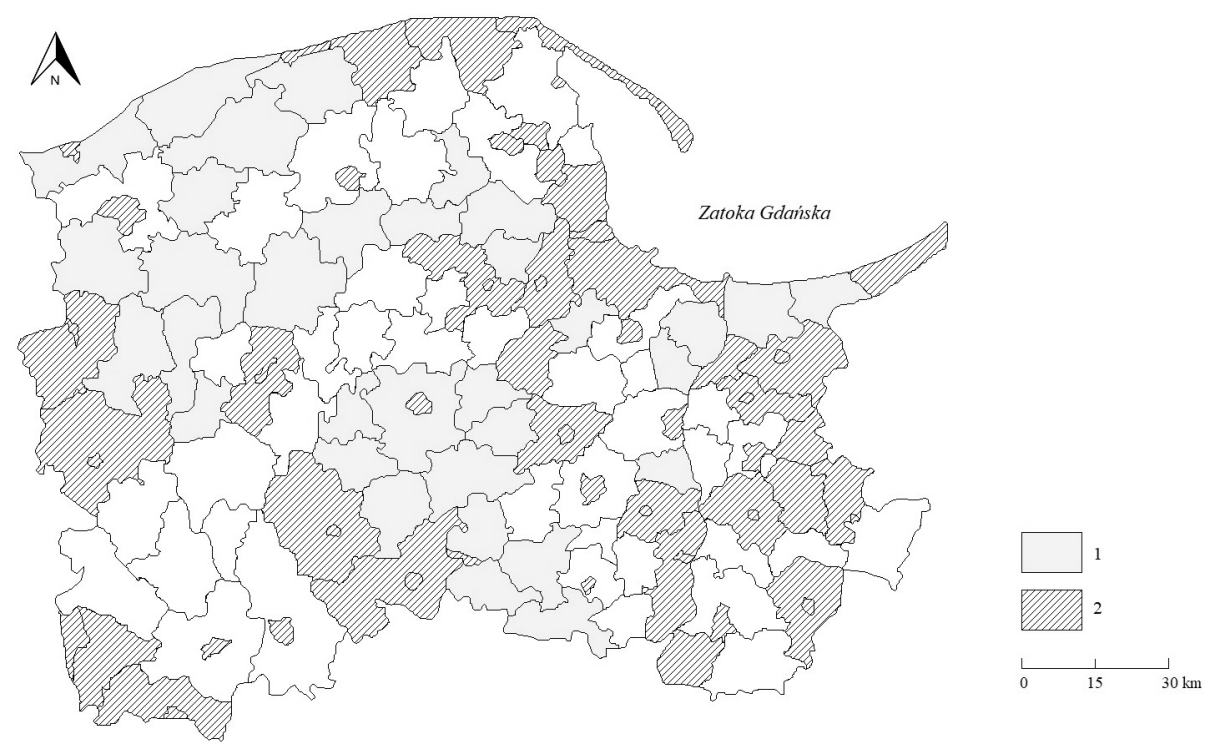

Ryc. 5. Turystyka krótkoterminowa w dokumentach strategicznych gmin wiejskich województwa pomorskiego 1 - gminy, których strategie wymieniają turystykę krótkoterminową, 2 - gminy nieobjęte badaniem Short-stay tourism in strategic documents of rural communes in the Pomorskie Voivodeship 1 - short-stay tourism mentioned in strategic documents, 2 - administrative units not included in the analysis

Uwzględniając w swoich dokumentach strategicznych nowe formy turystyki, wynikające ze zmieniającego się stylu życia, nowych wzorców spędzania czasu wolnego oraz postępującego procesu starzenia się społeczeństwa, gminy wiejskie województwa pomorskiego stwarzają odpowiednie warunki do rozwoju branży turystycznej, której oferta będzie odpowiadała na obecne i przyszłe oczekiwania turystów.

\section{Mocne i słabe strony, szanse oraz zagrożenia w kontekście rozwoju funkcji turystycznej gminy}

Jak już wcześniej wspomniano, analiza SWOT jest elementem każdej z analizowanych strategii rozwoju. Jest to powszechnie stosowana heurystyczna technika wykorzystywana do porządkowania i analizy danych. Nazwa SWOT to akronim od angielskich słów strengths, weaknesses, opportunities oraz threats, które określają cztery elementy składowe tego rodzaju analizy. Jest ona powszechnie stosowana jako narzędzie planowania strategicznego, które pozwala wykorzystać posiadane informacje do opracowania strategii działania opartej na szansach i silnych stronach. Jednocześnie umożliwia wyeliminowanie lub ograniczenie wpływu zidentyfikowanych słabych stron i zagrożeń na planowane działania.

Określając szanse, zagrożenia oraz mocne i słabe strony swoich gmin, władze lokalne wielokrotnie odnosiły się do kwestii związanych pośrednio i bezpośrednio z rozwojem branży turystycznej.

Spośród 74 badanych gmin tylko 5 (Tczew, Skórcz, Bobowo, Dębnica Kaszubska, Pszczółki) nie wskazało w analizie SWOT żadnych mocnych stron związanych z turysty- 
ką. W ogromnej większości zapisy w strategiach wskazywały na walory przyrodnicze jako mocne strony gmin (73\%), ponadto niektóre z nich wymieniały też obecność obszarów chronionych (15\%) oraz czyste środowisko (18\%). Nieco ponad połowa analizowanych gmin (52\%) wymieniła również walory antropogeniczne. Były to głównie zabytki architektury, ale wśród mocnych stron o charakterze pozaprzyrodnicznym znalazły się też folklor i tradycyjna kultura ludowa Kaszub, Żuław, Kociewia oraz Słowińców. W swojej strategii rozwoju Gmina Czarna Dąbrówka traktuje wielokulturowość jako podstawę rozwoju przemysłów kreatywnych, wymieniając ją również jako mocną stronę. Ponadto, niektóre zapisy odnoszą się również do organizowanych w gminach imprez cyklicznych, np. Tułacz i Harpagan w gminie Łęczyce. Poza różnego rodzaju walorami turystycznymi do mocnych stron zaliczane są także obiekty infrastruktury (26\%) oraz szlaki turystyczne. W kontekście rozwoju turystyki weekendowej i krótkookresowej, część gmin postrzega lokalizację blisko dużych ośrodków miejskich jako swoją mocną stronę. Są to gmina Przodkowo, Ryjewo, Miłoradz, Kobylnica i Potęgowo. Tylko jedna gmina wymienia partnerstwo publiczno-prywatne jako mocną stronę w swoim opracowaniu - jest to gmina Studzienice - „współpraca przy rozwoju usług turystycznych (prywatni przedsiębiorcy + władza samorządowa) ".

Kolejnym elementem analizy SWOT, stanowiącym element badania kontekstowego treści strategii rozwoju wybranych gmin, są ich słabe strony. W ramach prowadzonych badań wyselekcjonowano wyłącznie zapisy, które są powiązane z rozwojem turystyki w sposób bezpośredni lub pośredni. W grupie badanych gmin wiejskich zdecydowana większość (63 gminy) wskazały co najmniej jeden zapis tego typu. Wśród najczęściej wymienianych słabości znalazły się kwestie związane z brakiem odpowiedniej infrastruktury (54\% gmin), niedostateczną promocją walorów turystycznych (26\%), niewykorzystanym potencjałem turystycznym (19\%) oraz brakiem konkretnego produktu lub oferty turystycznej (14\%). Pozostałe problemy dotyczyły komunikacji (9\%) (np. brak parkingów, zły stan dróg, słabe oznakowanie miejsc atrakcyjnych turystycznie, brak ścieżek rowerowych), sezonowości atrakcji i usług turystycznych świadczonych w gminach (7\%), niskiej atrakcyjności turystycznej gminy (4\%), złego stanu obiektów zabytkowych (4\%), zbyt małych nakładów na turystykę i braku środków na renowację zabytków (3\%) oraz konkurencyjności pobliskiego ośrodka miejskiego (1\%; w tym przypadku dotyczyło to położenia w bliskiej odległości miasta Malbork) (ryc. 6).

Brak odpowiedniej infrastruktury to słaba strona, którą wymieniło aż 40 z 74 badanych gmin. Pośród identyfikowanych przez gminy niedostatków w tym zakresie najczęściej wymieniana była niewystarczająca liczba miejsc noclegowych lub ich niski standard (19 gmin). Ponadto, do słabych stron w zakresie infrastruktury zaliczano też braki w bazie gastronomicznej, brak infrastruktury umożliwiającej korzystanie z kąpielisk oraz brak ścieżek rowerowych.

Mimo, iż zasoby przyrodnicze wymieniane były jako mocne strony wielu gmin, to już formy prawne ich ochrony zaliczone zostały do słabych stron przez gminy Kościerskiego Obszaru Funkcjonalnego oraz gminę Kaliska. Według zapisów strategii obszary chronione ograniczają lub uniemożliwiają rozwój turystyki. Z drugiej strony, gmina Gniewino wskazuje skutki braku ochrony krajobrazu jako słabą stronę, co potwierdza zapis w brzmieniu: „przekształcone walory krajobrazowe i przyrodnicze w wyniku niekontrolowanego rozwoju przestrzennego zabudowy rekreacyjnej". Kwestia ochrony przyrody wspomniana zostanie jeszcze przy analizie zagrożeń związanych z rozwojem branży turystycznej, która poruszona zostanie w dalszej części artykułu. 


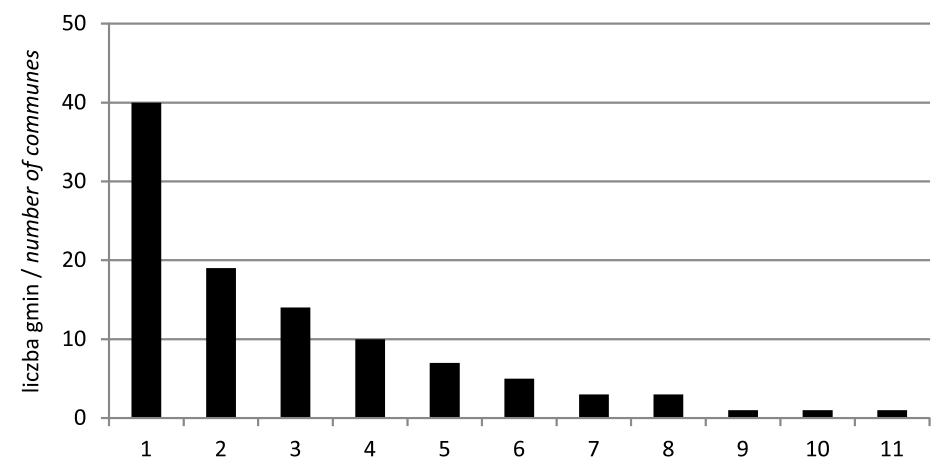

Ryc. 6. Słabe strony związane z rozwojem turystyki wskazywane w analizie SWOT, będącej częścią strategii rozwoju wybranych gmin wiejskich województwa pomorskiego

1 - brak infrastruktury, 2 - niewystarczająca promocja, 3 - niewykorzystany potencjał, 4 - brak produktu/oferty turystycznej, 5 - komunikacja, 6 - sezonowość usług turystycznych, 7 - niska atrakcyjność turystyczna, 8 - zły stan obiektów zabytkowych, 9 - zbyt małe nakłady na turystykę, 10 - brak środków na renowację zabytków, 11 - lokalizacja blisko ośrodka miejskiego Weaknesses related to tourism development being part of the SWOT analyses in strategic documents of rural communes in the Pomorskie Voivodeship

1 - lack of infrastructure, 2 - insufficient promotion, 3 - unused potential, 4 -lack of tourism product/offer, 5 -transport system, 6 - seasonality of tourism services, 7 -low tourism attractiveness, 8 - poor condition of historical objects, 9 - underinvestment in tourism sector, 10 - lack of funds for renovation of historical objects, 11 - location near the city/urban area

Niewątpliwie rozwój turystyki jest postrzegany przez władze lokalne jako szansa dla gminy - tylko pięć badanych jednostek nie wskazało żadnej szansy związanej z rozwojem tej branży w analizie SWOT, przeprowadzonej na potrzeby strategii rozwoju. W swoich strategiach gminy wymieniają szereg szans, które w sposób pośredni lub bezpośredni wiążą się z funkcją turystyczną. Ponad jedna trzecia gmin upatruje swoich szans w rozwoju infrastruktury (26 gmin; 35\%). Dotyczy to głównie rozwoju bazy turystycznej (noclegowej i gastronomicznej), ale także budowy ścieżek rowerowych, przystani oraz innych obiektów rekreacyjnych. Ponadto władze lokalne widzą szansę rozwoju swoich jednostek w zwiększającym się popycie na usługi turystyczne (16 gmin, 22\%), w rosnącym zainteresowaniu agroturystyką i turystyką wiejską (23 gminy, 31\%) oraz w związku z modą na aktywne spędzanie czasu wolnego i zdrowy styl życia (14 gmin, 19\%), wspominając przy tym o turystyce rowerowej i wodnej oraz produktach ekologicznego rolnictwa. W kategorii szans wymieniona została także lokalizacja: 6 gmin (8\%) wskazało, że szansą jest korzystne położenie blisko miast (Trójmiasto, Słupsk, Malbork, Kwidzyn), natomiast aż 22 gminy (30\%) dostrzegają korzyści w położeniu blisko obszarów atrakcyjnych kulturowo (Kociewie) i przyrodniczo (np. nad Wisłą - gmina Subkowy; w Borach Tucholskich - gmina Kaliska; na obszarach Natura 2000 - gmina Dębnica Kaszubska; w pobliżu Morza Bałtyckiego gmina Kobylnica). Jako szansę w dokumentach wymieniano także wykreowanie nowego produktu turystycznego lub poszerzenie już istniejącej oferty turystycznej (16 gmin, 22\%). Kolejnymi kwestiami wymienianymi w kategorii szans były: promocja (11 gmin, 15\%), zarówno poprzez budowę nowych obiektów, jak i popularyzację walorów kulturowych Kaszub i Kociewia; sieciowość i współpraca (10 gmin, 14\%) na różnych poziomach - zarówno pomiędzy gminami, jak i sektorami: prywatnym i państwowym; realizacja określonego projektu (7 gmin, 9\%), np. wytyczenie trasy nordic walking i narciarstwa biegowego (gmi- 
na Trzebielino), budowa Skansenu Wsi Europejskiej (gmina Smołdzino), realizacja Wiślanej Trasy Rowerowej (gminy Miłoradz oraz Cedry Wielkie). Pozostałe, pojedyncze wskazania dotyczyły tworzenia odrębnych dokumentów strategicznych dla rozwoju turystyki oraz wzrostu poziomu życia poprzez rozwój turystyki.

Ostatnim elementem analizy SWOT są zagrożenia. Tylko 39 z 74 gmin dostrzega jakiekolwiek zagrożenia związane z rozwojem turystyki. „Zwiększony, niekontrolowany ruch turystyczny powodujący degradację walorów przyrodniczych" to najczęściej powtarzające się zdanie, w przypadku kilku gmin występujące w dokumentach dosłownie w tym samym brzmieniu. Nie tylko ogólność zapisów w kategorii „Zagrożenia”, ale także ich treść budzi zastrzeżenia. Dla kilku gmin przepisy dotyczące ochrony zabytków oraz formy prawne ochrony zasobów przyrodniczych stanowią zagrożenie: „Ograniczenia wynikające z objęcia części Gminy siecią obszarów Natura 2000” (gminy Studzienice oraz Dębnica Kaszubska); „Ograniczenia rozwojowe, wynikające z przepisów o ochronie środowiska naturalnego, zabytków itp." (gmina Wejherowo). Ponadto, pomimo iż niektóre gminy wymieniły „współpracę” i „sieciowość” jako szanse, analiza zagrożeń wskazała, że rozwój funkcji turystycznej w gminach sąsiadujących postrzegany jest przez 21 gmin (28\%) jako zagrożenie, a nie szansa dla całego regionu.

Podsumowując, analiza kontekstowa wszystkich czterech elementów narzędzia planowania strategicznego SWOT wskazuje, iż turystyka oraz powiązane z nią zjawiska i procesy są postrzegane głównie w kontekście pozytywnym i wymieniane przeważanie jako szansa lub dobra strona gminy.

\section{Podsumowanie}

Turystyka, jako istotny kierunek rozwoju wielu gmin wiejskich województwa pomorskiego, uwzględniana jest jako cel strategiczny, główny lub operacyjny przez 92\% badanych jednostek. Ponadto, turystyka oraz powiązane z nią zjawiska i procesy brane są pod uwagę w analizie SWOT, stanowiąc zarówno dobre i złe strony, jak i zagrożenia lub szanse dla regionu. Atrakcyjność turystyczna gminy wraz z opisem walorów naturalnych i antropogenicznych jest również podejmowana w analitycznej części dokumentów, gdzie diagnozowany jest aktualny stan danej jednostki administracyjnej.

Planowanie rozwoju lokalnego to niezwykle złożony i wieloetapowy proces, obejmujący zaangażowanie nie tylko władz lokalnych, ale również wielu instytucji, organizacji oraz partnerów prywatnych i wreszcie samych mieszkańców. Aby proces ten przebiegał poprawnie, gminy konstruują dokumenty strategiczne. Strategia rozwoju gminy nie jest dokumentem obligatoryjnym, ale jej opracowanie jest kluczowym elementem zarządzania rozwojem jednostki samorządu terytorialnego (Parysek 2015). Struktura strategii, obejmująca analizę aktualnego stanu gminy oraz zadania i cele, które stawia sobie gmina, pozwala na uporządkowanie informacji oraz efektywną realizację przyjętego planu rozwoju.

Jednakże, aby dokument strategiczny był efektywny, musi on być poprawnie skonstruowany - wytyczać jasno sformułowane, konkretne i możliwe do realizacji cele. Sposób, w jaki formułowane są cele, jest również istotny z punktu widzenia późniejszej ewaluacji przyjętej w dokumencie ścieżki rozwoju. W przypadku strategii rozwoju dla gmin wiejskich województwa pomorskiego, w kontekście rozwoju turystyki, należy stwierdzić, że analizowane dokumenty w większości nie spełniają tego wymogu. Po pierwsze, uwagę zwraca 
bardzo duży poziom ogólności przyjętych do realizacji celów operacyjnych. Jedynie w nielicznych przypadkach nawiązują one do konkretnych obiektów lub obszarów, stanowiąc jasno wytyczone zadania, których realizację będzie można jednoznacznie ocenić po zakończeniu określonej w dokumencie perspektywy czasowej. Konstruując cele, zarówno strategiczne, jak i operacyjne, gminy posługują się utartymi sloganami, często przytaczając je dokładne w tym samym brzmieniu. Sprawia to, że dokument staje się oderwany od specyfiki danej jednostki administracyjnej i jednocześnie pozwala każde zrealizowane przedsięwzięcie zaliczyć na poczet danego celu strategicznego, co w zasadzie uniemożliwia rzetelną ewaluację realizacji przyjętych celów. Po drugie, rozwój turystyki postrzegany jest głównie w kategoriach rozbudowywania infrastruktury z pominięciem czynnika ludzkiego, a świadczenie usług turystycznych wymaga odpowiedniego kapitału ludzkiego. By rozwój turystyki przyczyniał się do wzrostu poziomu i jakości życia mieszkańców, co postuluje większość gmin w swoich wizjach lub misjach, winien on angażować ludność lokalną, która jednak powinna posiadać pewne określone umiejętności. Gminy wiejskie zupełnie pomijają ten aspekt rozwoju branży turystycznej w swoich dokumentach strategicznych. Zarzut zbyt dużej ogólności sformułowań odnosi się również do analiz SWOT - zaliczając zapis w brzmieniu „rozwój turystyki” do kategorii „zagrożenia” lub „szanse” nie pozostawia wątpliwości, że analiza przeprowadzona została pobieżnie i w zasadzie nie pozwala na wyciągnięcie jakichkolwiek konstruktywnych wniosków. Ponadto, zdarza się, że gminy umieszczają ten sam zapis w dwóch kategoriach, np. traktując turystykę jako dobrą i złą stronę jednocześnie, nie podając żadnych wyjaśnień, w jakim aspekcie jest ona negatywna lub pozytywna. Sporządzona w taki sposób analiza SWOT nie może zatem spełniać swojego zadania i pozostaje martwym elementem dokumentu. Niepokojące jest również to, że tak mało gmin dostrzega w rozwoju turystyki zagrożenie. Natomiast duża część gmin, która umieściła kwestie związane z turystyką w tej kategorii, skopiowała ten sam ogólny zapis, o którym wspomniano w poprzednim rozdziale, dając jednoznacznie do zrozumienia, że nie traktuje tego rodzaju zagrożenia poważnie oraz, że nie została przeprowadzona żadna analiza zagrożeń generowanych przez wzmożony ruch turystyczny na potrzeby tworzonej strategii rozwoju, uwzględniająca konkretne obszary recepcji turystycznej i ich walory.

Jednakże najbardziej zaskakującym zjawiskiem jest postrzeganie gmin sąsiednich jako niebezpiecznej konkurencji. Wydaje się, że gminy nie dostrzegają lub nie doceniają pozytywnych aspektów sieciowania i współpracy w zakresie rozwoju turystyki w regionie.

Natomiast do pozytywnych trendów, które ujawniła analiza dokumentów strategicznych gmin wiejskich województwa pomorskiego, zaliczyć należy zwrócenie się ku turystyce aktywnej i zielonej oraz zauważalne odejście od rozwijania tradycyjnych form masowej turystyki wypoczynkowej. Ma to również swój wyraz w promowaniu turystyki krótkookresowej, skierowanej ku osobom zamieszkującym okoliczne miasta, zwłaszcza w gminach otaczających Trójmiasto. Z drugiej strony, wiele gmin postrzega bezpośrednie sąsiedztwo miast (Kwidzyn, Malbork) jako zagrożenie i konkurencję, nie biorąc pod uwagę odmiennej specyfiki, jaką charakteryzuje się turystyka miejska i nie dostrzegając komplementarnej roli, którą może odgrywać ich oferta.

Podsumowując, poddane analizie strategie rozwoju gmin wiejskich województwa pomorskiego nie spełniają w pełni swojej roli w kontekście planowania rozwoju turystyki w wybranych jednostkach administracyjnych. Pozostaje jedynie mieć nadzieję, że inne, tworzone w niektórych gminach dokumenty (np. oddzielnie uchwalane strategie rozwoju 
turystyki oraz inne dokumenty planistyczne) w sposób pełniejszy wyznaczają ścieżki rozwoju branży turystycznej. Ponadto, zaangażowanie samych mieszkańców oraz organizacji i stowarzyszeń (np. Klub Nowodworski, Stowarzyszenie Kochamy Żuławy lub Stowarzyszenie Produktów Markowych Turystyki Wiejskiej „Słupia”) stwarza niezależne od oficjalnych dokumentów strategicznych warunki do poprawnego i zrównoważonego rozwoju turystyki w analizowanych gminach wiejskich.

\section{Bibliografia}

Bocian A., 2003, Problemy budowy regionalnych strategii, [w:] M. Adamowicz (red.), Strategia rozwoju lokalnego. Tom 1. Aspekty instytucjonalne, SGGW, Warszawa.

Bosiacki S., 2016, Turystyka aktywna w strategii rozwoju turystyki w województwie wielkopolskim, Ekonomiczne Problemy Turystyki, 1, 33, s. 151-162.

Brodziński Z., 2011, Stymulowanie rozwoju obszarów wiejskich na poziomie lokalnym na przykładzie gmin województwa warmińsko-mazurskiego, Wydawnictwo SGGW, Warszawa, s. 172-192.

Dogru T., Bulut U., 2018, Is tourism an engine for economic recovery? Theory and empirical evidence, Tourism Management, 67, s. 425-434.

Gawroński H., 2010. Zarzqdzanie strategiczne w samorzqqach lokalnych, Wolters Kluwer Polska, Warszawa.

Idziak W., 2002, Rola strategii gminnej w aktywizacji społeczno-gospodarczej gminy Malechowo, [w:] M. Kłodziński, B. Fedyszak-Radziejowa (red.), Przedsiębiorczość wiejska w Polsce i krajach Unii Europejskiej, IRWiR PAN, Warszawa, s. 410-427.

Klasik A., Kuźnik F., (red.), 2001, Zarzq̨dzanie strategiczne rozwojem lokalnym i regionalnym, Wydawnictwo Akademii Ekonomicznej w Katowicach, Katowice.

Kłodziński M., 2009, Znaczenie i potrzeba tworzenia strategii rozwoju gminy, Zagadnienia Ekonomiki Rolnej, 319, 2, s. 33-47.

Kogut-Jaworska M., 2011, Procedura budowy strategii rozwoju lokalnego i regionalnego, [w:] A. Szewczuk, M. Kogut-Jaworska, M. Zioło (red.), Rozwój lokalny i regionalny. Teoria i praktyka, Wydawnictwo C.H. Beck, Warszawa, s. 142-188.

Kozak M. W., 2010, Turystyka: niewykorzystana szansa rozwoju regionów? Studia Regionalne i Lokalne, 42, 4, s. 43-59.

Lisiński M., 2004, Metody planowania strategicznego, PWE, Warszawa.

Parysek J.J., 2008, Podstawy gospodarki lokalnej, Wydawnictwo Naukowe Uniwersytetu im. Adama Mickiewicza w Poznaniu, Poznań.

Parysek J.J., 2015, Rola lokalnego samorzqdu terytorialnego w rozwoju społeczno-gospodarczym i przestrzennym gmin, Ruch Prawniczy, Ekonomiczny i Socjologiczny, 3, s. 27-46.

Pawlikowska-Piechotka A., 2013, Planowanie przestrzeni turystycznej, Wydawnictwo Novae Res, Gdynia.

Szewczuk A., 2011, Filozofia i praktyka zarzqdzania rozwojem lokalnym, [w:] A. Szewczuk, M. Kogut-Jaworska, M. Zioło (red.), Rozwój lokalny i regionalny. Teoria i praktyka, Wydawnictwo C.H. Beck, Warszawa, s. 89-141.

Sztando A., 2009, Przedmiot i podmiot strategii rozwoju gminy, Zeszyty Naukowe Uniwersytetu Szczecińskiego, 526, seria Ekonomiczne Problemy Usług, 29, s. 467-473.

Sztando A., 2011, Istota i funkcje samorzqdowego planowania strategicznego w regionie, Prace Naukowe Uniwersytetu Ekonomicznego we Wrocławiu, 180, s. 45-55. 
Szwacka-Mokrzycka J., 2012, Znaczenie turystyki w strategii rozwoju gminy, Studia Ekonomiczne i Regionalne, 5, 1, s. 28-33.

Ślusarz G., 2006, Zarzqdzanie rozwojem przez jednostki samorzqdu terytorialnego - specyfika, potrzeby, wyzwania, Problemy Zarządzania, 3, s. 45-51.

UNWTO Tourism Highlights 2017 Edition, 2018, http://mkt.unwto.org/publication/unwto-tourism-highlights (07.05.2018).

Wiatrak A.P., 2011, Strategie rozwoju gmin wiejskich. Podstawy teoretyczne, ocena przydatności i znaczenie w przemianach strukturalnych obszarów wiejskich, Wydawnictwo IRWiR PAN, Warszawa, s. 25-76.

Wilkin J., 2004. Dlaczego potrzebujemy długookresowej strategii zintegrowanego rozwoju wsi i rolnictwa w Polsce, Wieś i Rolnictwo, 123, 2, s. 157-170.

Wojtasiewicz L., 2003, Powiaty w strategiach rozwoju lokalnego i regionalnego, [w:] M. Adamowicz (red.), Strategia rozwoju lokalnego. Tom 1. Aspekty instytucjonalne, SGGW, Warszawa, s. 301-324.

Wołowiec T., Reśko D., 2012. Strategia rozwoju gminy jako narzędzie zarzqdzania zmianq gospodarczq, Zeszyty Naukowe WSEl seria: Ekonomia, 5, 2, s. 61-89.

\section{Summary}

Tourism continues to be one of the world's largest industries and its total impact is impressive. This economic sector has boasted virtually uninterrupted growth over time, despite occasional shocks, demonstrating its strength and resilience. In 2017, it contributed to $10 \%$ of the global GDP. For this reason, in the UNWTO Tourism Highlights (2017) it has been called a key to development, prosperity and well-being. However, some negative issues and social problems, like alcoholism, deterioration of local tradition or teen prostitution, triggered by uncontrolled development of tourism industry are often silenced. The real nature of the relationship between tourism and regional socio-economic growth is of particular importance to local authorities and policy makers. Nowadays, about $80 \%$ of local authorities in Poland perceive tourism as a basic or complementary direction of socio-economic development, as researched by A. Pawlikowska-Piechotka (2013). Therefore, the main aim of this study was to answer the question how tourism is perceived by local authorities of rural communes in the Pomorskie Voivodeship and to what extend its development is deliberately planned in their strategic documents. In order to achieve such an objective, the author analysed current strategic documents issued by 74 rural communes using computer and context analysis methods. The author analysed more than 5860 pages in total. Special attention was paid to two selected sections of the documents: strategic and operational objectives as well as the SWOT analysis. These were analysed in the context of tourism development. The research has revealed that examined documents are not an effective and sufficient tool for tourism development as they are too general and lacking realistic goals to be evaluated in the future. 